\title{
A Case for Reverse Incorporation of Academic Legal Scholarship into Conflict Management Studies
}

\author{
Annie de Roo*
}

\begin{abstract}
The article takes as its point of departure some of the author's multidisciplinary projects. Special attention is given to the question of whether the disciplines united in the various research team members already constituted a kind of 'inter-discipline', through which a single object was studied. The issue of how the disciplinary orientations of the research team members occasionally clashed, on methodological issues, is also addressed.

The outcomes of these and similar multidisciplinary research projects are followed back into legal practice and academic legal scholarship to uncover whether an incorporation problem indeed exists. Here, special attention will be given to policy recommendations and notably proposals for new legislation. After all, according to Van Dijck et al., the typical role model for legal researchers working from an internal perspective on the law is the legislator.

The author concludes by making a somewhat bold case for reverse incorporation, that is, the need for (traditional) academic legal research to become an integral part of a more encompassing (inter-)discipline, referred to here as 'conflict management studies'. Key factors that will contribute to the rise of such a broad (inter-)discipline are the changes that currently permeate legal practice (the target audience of traditional legal research) and the changes in the overall financing of academic research itself (with special reference to the Netherlands).
\end{abstract}

Keywords: legislator, legal research, academic research, conflict management studies, inter-discipline

\section{Introduction}

The central question running through this Erasmus Law Reviem special issue is: 'How can we translate and incorporate the various non-legal disciplines and their findings into the language of legal doctrine?' Adequate evaluation of positive law requires at least some critical distance regarding the law and inclusion of insights from other relevant disciplines. Yet at the same time, such (partially) external insights are not easily incorporated into the internal perspective of doctrinal legal analysis.

* Erasmus School of Law, Erasmus University Rotterdam.
In their introductory contribution to this issue, Sanne Taekema and Wibren van der Burg have argued that the opposition between legal doctrinal research and interdisciplinary research must be transcended.

At the 2014 symposium that constituted the precursor of this special issue, I was asked to address this incorporation problem on the basis of one or more concrete case studies. In view of my involvement in several multidisciplinary research projects, I have taken the liberty to take four of these projects as the basis for my analysis. This choice has enabled me to rethink, as an insider, whether such an incorporation problem has indeed surfaced and if so, when and how. In doing so, I will make an effort to tie my own experiences in with ongoing discussions and observations reported by others in academic literature.

At the outset, I should clarify that my track record in academic research has developed mainly in the domain of comparative law and from there into the comparative analysis of dispute resolution methods. Thus in my research, solutions offered through (domestic) law always had to be juxtaposed, either to foreign legal solutions or to solutions achieved through strategies other than 'juridification' and litigation in a court of law. There were, therefore, always two axes of comparison on the horizon.

Differences and similarities observed through such juxtapositions require explanations or at least an effort thereto. As scientific explanation cannot be generated from within an internal legal research perspective, it is not surprising that comparative law and comparative dispute resolution are fields where external perspectives on law are traditionally brought in, through disciplines such as political history, sociology, conflict psychology, game theory, and economics. ${ }^{1} \mathrm{My}$ former head of department in comparative law even devoted her inaugural lecture to the need for multidisciplinary research in teams and quoted the following ironical observation made by Feldbrugge:

When lawyers as a side-line indulge in what they consider scientific work, their method is usually to take up a subject, read and think about it, and hope vaguely that all this will result in conclusions which are in some way interesting, useful, surprising etc. The

1. On the distinction between the internal and external method, see, inter alia, R. Dworkin, Law's Empire (1986). 
choice of a subject is dictated by personal taste (of the author himself, his publisher, his boss etc.) and there are almost no rules concerning research methods, except the one which says that the more legal provisions, cases and other material you read, the better the research. ${ }^{2}$

On a personal note: studying legal rules just for the sake of those rules and their coherence within a legal system has never truly caught my fascination. I have always been more interested in the real world, notably in what drives key actors to press for rules and what makes the addressees, involved in a conflict, decide to go for a rule-based strategy or not to end the conflict. In the real world, resorting to law is just one out of many ways to address conflicts.

Hereafter, in part 2, I will first describe the gist of four multidisciplinary projects I was involved in. Special attention will be given to the question of whether the disciplines united in the various research team members already constituted a kind of 'inter-discipline', through which a single object was studied. The issue of how the disciplinary orientations of the research team members occasionally clashed, on methodological issues, will also be addressed. At any rate, the outcomes of these multidisciplinary projects were largely based on insights from the empirical sciences. The central theme connecting all projects was human conflict strategies and governance. The conflict strategies always encompassed authoritative judicial intervention as opposed to informal conflict and problem resolution, procured by disputants autonomously (including mediation). The governance levels ranged from the state level (in projects 1 and 2) to corporate and family levels (projects 3 and 4).

It makes sense to move beyond the four projects next, in part 3 (building blocks of a human conflict inter-discipline), to gain a more comprehensive overview of the development of research generally, at the crossroads of judicial and autonomous conflict resolution. Although in recent times empirical insights from various disciplines seem to have become hijacked for governmental austerity agendas, truly useful insights can still be distilled.

As a next step (part 4), an attempt is made to uncover whether a problem of incorporating such empirical findings into legal doctrine indeed exists. Here, special attention will be given to policy recommendations and notably proposals for new legislation. After all, according to Van Dijck et al., the typical role model for legal researchers working from an internal perspective on the law is the legislator. ${ }^{3}$ Whenever this legislator role model is adopted, Taekema and Van der Burg speak of legal doctrinal research in a broad sense.

As the four projects were all commissioned by the Netherlands' government, the incorporation issue will neces-

2. F.J.M. Feldbrugge, 'Sociological Research Methods and Comparative Law', in M. Rotondi (ed.), Inchieste di Diritto Comparato, Vol. 2: Aims and Methods of Comparative Law (1973), at 215.

3. G. van Dijck, S. van Gulijk \& M. Prinsen, 'Wat doet de juridische onderzoeker?', 31 Recht der Werkelijkheid 1, at 44ff. (2010). sarily be analysed in regard to Dutch law and doctrinal research only. In regard to my home jurisdiction, I come to the conclusion that the insights generated by the empirical sciences (broadly referred to as 'conflict management studies') are essentially 'cannibalised' in legal doctrinal research and publications: only those findings are incorporated that can be translated into doctrinal legal concepts.

I will conclude my contribution (part 5) by making a somewhat bold case for reverse incorporation, that is, the need for (traditional) academic legal research to become an integral part of the more encompassing (inter-)discipline referred to as 'conflict management studies'. Key factors that will contribute to the rise of such a broad (inter-)discipline are the changes that currently permeate legal practice (the target audience of traditional legal research) and the changes in the overall financing of academic research itself (with special reference to the Netherlands). Arguably, such reverse incorporation goes one step further than, for instance, Sullivan's view that legal doctrinal research itself is interdisciplinary and in that particular sense distinctive. ${ }^{4}$ That view leans heavily on a one-way infusion of empirical insights into autonomous legal research, whereas I believe there are good reasons to - conversely - impart insights from the law into at least those branches of the empirical sciences that concern themselves with human conflict.

Law with its concern for equal protection may be instrumental in completing the quarter-turn rotation that I plead, away from the austerity bias in empirical studies towards restoration of a true vista on human conflict resolution.

\section{Some Multidisciplinary Projects Reconsidered}

Four projects are considered here, on a two-by-two basis.

\subsection{Bench Marking and Court-Referred Mediation}

The first two projects focused on the administration of justice in different European legal systems and the role therein of mediation. It may be helpful to view the handling of litigation by courts as a provision of state-funded 'judicial' services that can be studied from the supply side but also from the demand side. The first project, Bench Marking - An international comparison of the mechanisms and performance of the judiciary system, concentrated on the supply side. ${ }^{5}$ It had been commissioned by the Netherlands Council for the Judiciary to a team of economists and comparative lawyers. The targeted audience of this research was, in a sense, the Treasury.

4. K.M. Sullivan, 'Foreword: Interdisciplinarity', Michigan Law Review, at 1217-1226 (2007).

5. J. Blank, M. van der Ende, B. van Hulst \& R. Jagtenberg, Bench Marking in an International Perspective. An International Comparison of the Mechanisms and Performance of the Judiciary System (2004). 
Are there any objective standards by which the Treasury can decide whether more or less resources should be invested in the judiciary, lacking a genuine market mechanism for judicial services? The answer that presents itself is by comparing the input/output ratio of the Dutch judicial system to the input/output ratios for the judiciary in neighbouring countries. 'Input' was operationalised as financial resources invested in salaries and equipment and 'output' as number of cases decided and processing time. What we are looking at here is, in other words, the productivity, or business efficiency, of the courts. At this point, legal academics and practitioners may wonder: aren't these data at a much too aggregated level? Many intermediate factors of a technical-legal nature will be co-determinant of, for instance, the number of judgments produced. It became indeed the role of the legal academics and practitioners to qualify the results delivered through the dominant method of quantitative economic analysis in this project, one such intermediary factor being the availability and use of informal mechanisms such as mediation.

This takes us to the second project, the Practice of Courtreferred Mediation in Countries neighbouring the Netherlands. ${ }^{6}$ This time, the focus was primarily on the demand for judicial services, albeit that a central issue was how this demand could be manipulated, by granting the courts power to mandatorily refer litigants to mediation or, at the other extreme, by leaving it up entirely to the parties to opt for mediation voluntarily, whenever litigation was considered. Naturally, we were also interested in any arrangements representing shades of grey in between these black and white extremes. This project was commissioned by the Netherlands Ministry of Justice, and it ran parallel to a purely domestic investigation, monitoring the first nationwide experiments with court-referred mediation in this country. In the Dutch experiment, the mediation option was explained to litigants by letter or orally by the judge, but in the end, it was for the parties to decide whether to choose mediation or to continue with their litigation in court. During the experiment, mediation was also available free of charge for litigants. The Ministry was interested, however, to what extent the number of mediated settlements would rise or fall if parties would be more or less pressed into mediation and/or when they would have to pay for the services of a mediator themselves. Manipulating these variables within a first national experiment would make the domestic research design too complicated, but as it was well known that neighbouring countries had various costs arrangements in place while operating by varying degrees of compulsion, a comparative (European) format was again resorted too. The other disciplines represented in this project were sociology of law and policy administration: most of the available empirical studies in the other European countries (that our project sought to synthesise) can be characterised as sociolegal

6. A. de Roo and R. Jagtenberg, De praktijk van mediation in ons omringende landen (2003). Presently the ministry is referred to as the Ministry of Security and Justice. research, while the overall monitoring of the project was shared between legal academics and government officials trained in policy administration.

\subsection{Costs and Opportunities and Multiproblem} Families

The focus of the third and the fourth project was not on the state level of governance, but on the corporate level and on the family level, respectively. Both these projects were domestic in outlook and concentrated on the different pathways for dealing with developing conflicts and on the amounts of escalation and costs arising along these various pathways. Project 3, Costs and Opportunities: an Inquiry into Individual Labour Conflicts within the Dutch Police Force, was commissioned by an agency representing both the employees and the employer of the Netherlands police, i.e. the police trade unions, and (at that time) the Ministry of the Interior. ${ }^{7}$

The aim was to uncover what disputants themselves perceived as the ultimate cause of the conflicts at work they had become involved in and to ascertain the relative frequency of formal (rule-based) and informal (negotiation-based) approaches to end the conflict. The obvious formal approach is by imposing orders (the employer) and appealing against such orders through the civil servant courts (the employee); informal approaches would include direct negotiation as well as mediation. Last but not least, the costs to be associated with these approaches were to be assessed. The research team consisted of legal scholars and economists, and the target audience was the said agency. Both agency partners, i.e. the government employer and the unions, were interested to see what organisational costs and personal costs were involved in each approach and, if necessary, to put this as a key HRM issue on the national agenda.

Whereas policemen are, on average, reasonably well educated and conversant with the law, the opposite tends to be true for the population in the fourth project: the members of multiproblem families. This project, Socio-economic Returns on Family Group Conferencing for Dutch Multi-Problem Families, was commissioned by the non-profit foundation that facilitates family group conferences in the Netherlands, the EKC (Eigen Kracht Centrale). ${ }^{8}$ Where a family is in trouble (e.g. poverty, educational failure, youth delinquency, housing problems), the members of the family network themselves can be activated to solve (part of) these problems autonomously, without outside intervention by professionals (psychologists, the judiciary issuing supervision orders). To this end, the conferences are convened with EKC assistance. Other researchers had already established that the quality of solutions achieved through the family group approach did not differ much from outcomes achieved through professional interventions. In our project,

7. R. Jagtenberg, A. de Roo, J. Blank \& B. van Hulst, Kosten en kansen. Een onderzoek naar individuele arbeidsconflicten binnen de Nederlandse politie (2006).

8. A. de Roo and R. Jagtenberg, 'Socio-Economic Returns on FGC for Dutch Multi-Problems Families', in R. Clarijs and Th. Malmberg (eds.), The Quiet Revolution (2012), at 149-60. 
we had to find out about the costs to be associated with the autonomous approach as opposed to an interventionist approach. Again the methodological device of conflict development pathways was used, and again the research team consisted of economists and legal scholars. The target audience was the community of youth care professionals and the responsible government ministries, the purpose being to make them aware of the cost implications of each choice (autonomy or intervention) in their decision-making process.

\subsection{Clashes between Disciplines}

I now come to the question of whether the disciplines represented by the research team members already constituted a kind of 'inter-discipline' and how the disciplinary orientations of the research team members occasionally clashed, on methodological issues.

Staying in line with the symposium discussions, I will define an inter-discipline as a joint enterprise fuelled by different vested academic disciplines (such as law, economics, psychology), where there is a single research object, a common target audience, and a single underlying rationale for doing the research, whereby use is made of various discipline-specific methods cumulatively; upon mutual agreement, one particular method may have been selected as the dominant (or primary) method. A once-only project carried out this way does not establish a new inter-discipline yet. Only when a novel particular combination of disciplines and methods is used time and again to study a single object (usually because peers will have accepted the combination as adding significantly to scientific knowledge) then we may speak of an (acknowledged and accepted) inter-discipline.

In this sense, law and economics is such an inter-discipline, whereby legal rules are the object and the microeconomic toolbox constitutes the dominant method. Are research projects 1, 3, and 4 (Bench Marking, Costs and Opportunities, and Multi-problem Families) for that reason to be characterised as law and economics projects? I would say no.

As to Bench Marking, the emphasis is not on the allocative efficiency of legal rules as the end product of legal systems, but on the productive efficiency of the key actors producing such rules (whatever their contents). This emphasis has allowed more legal scholarship and practical experience to play a role, in interpreting the quantitative data and formulating conclusions. Both disciplines being allowed to play a role, (friendly) 'clashes' or rather corrections by the legal researchers occurred both in regard to the research design and in regard to the interpretation of outcomes. Thus it became clear soon that it would not be so hard to find key data such as the number of judges per 100.000 inhabitants and the number of cases concluded per 1,000 inhabitants. As legal scholars, bearing in mind that there are numerous aspects of national legal cultures involved as intermediate variables contributing to the input/output figures, variables that could turn the whole exercise into an 'apples and oranges' comparison, a methodological 'case' was made (and 'won') to plot the legal systems under survey along some key legal features ('descriptors') likely to be co-determinant of the output data. ${ }^{9}$ Although it turned out to be virtually impossible to ascertain the precise impact of all these intermediate variables on the input and output figures, at least these figures were now related to their larger context and warned the reader to handle the key data found as merely indicative and requiring careful interpretation. For example, courts in Poland appeared to be much more productive (in terms of cases decided per judge) than courts in the Netherlands. Here the insights of the legal scholars and notably the legal practitioners in the project supervisory committee (e.g. a member of a European association of judges) were crucial in identifying a relationship between court performance and the availability of informal dispute resolution schemes (ADR). A plausible interpretation of the figures that presented itself then was that in countries with many ADR filter mechanisms, such as the Netherlands, the simple disputes are filtered out, so that the more complicated cases remain to be solved by the courts; and these remaining complex cases will take much more time to decide, hence less cases decided per judge. Whereas courts in a country that lacks ADR filters, like Poland, can retain large numbers of relatively simple cases that will easily push up total output figures, giving the impression of great efficiency - an interesting example of how misleading quantitative data and pure economic productivity analysis may be.

Could project 3, Costs and Opportunities, be characterised then as materialising the inter-discipline of law and economics? Again, the answer should be no. In this project, the methods used by the economists largely bordered on accountancy, pricing particular services and interventions, and procuring the quantitative analysis. The same applies to project 4, on Multi-problem Families. Here, however, an interesting clash surfaced during an on-the-side conference involving researchers specialised in the field of professional youth care interventions versus family group self-help. The focal point was the randomised controlled trial (RCT) method. The RCT method is regarded as the 'golden standard' in pharmaceutical research to test new medical drugs. Patients are randomly selected for an experimental group (that receives the new drug) and a control group (receiving a placebo). Now some experimental psychologists argued that this method must also be deployed to test professional youth care interventions and even to test the effectiveness of families resorting to their own networks for assistance with a variety of pedagogical problems. However, in regard to the latter, Dutch law prescribes that resorting to one's own family network for making a sound plan is a fundamental right, at least in those cases where judicial intervention through issuance of a court supervision order (ondertoezichtstelling) is pending. Only where the EKC-supported family network itself cannot come up with a sound plan, minors

9. J. Blank et al., above n. 5, p. $20 f f$ 
can be subjected to (court imposed) professional youth care interventions.

The clash of methods between the 'hard core' psychologists and the legal researchers translates as: should the support activities by the family network members - lay persons, on the whole - be conceived of as 'intervention techniques' at all or as addressees of the law exercising their legal rights? And if one were to compare the effectiveness of both approaches (professional interventions versus family group self-help) just the same, does not the status of a right prevent randomisation here? Conversely, the RCT hardliner might say that any experiment involving the EKC-supported experimental group and a control group will in that case be (statistically) biased.

Finally, project 2 (Court-referred Mediation) did not involve economic analysis; this was rather a meta-analysis of a number of domestic sociolegal studies from across Europe on the practices of court referrals. A key finding of this analysis was that more compulsion exerted on litigants to take their case to mediation will result in a smaller percentage of referred cases being settled successfully. This finding led to some (friendly) 'clashes' with supervisory committee members with a background in public policy administration. For example, the 'public administrators' opined that percentages only give one side of the picture, whereas absolute numbers may be more informative from a policy-making point of view. More concrete: take a sample of 1,000 pending court cases. If a voluntary referral scheme leads to $2 \%$ referrals, whereby $75 \%$ of these referred cases are settled successfully, this means that in the end, 15 cases are taken out from the court dockets. If a mandatory referral scheme leads (obviously) to $100 \%$ referrals and 15\% referred cases being settled successfully, that gives 150 cases taken out from the docket. This is ten times as much. The 'policy administrators' emphasised that for the development of a budgeting policy, the absolute numbers would make it interesting to consider the mandatory approach. From the legal researcher's point of view, however, the percentages were more important, as these reveal that in mandatory referral schemes, $85 \%$ of all litigants may have left the mediation room with a feeling that they have been forced to waste their precious time; and these likely frustrated litigants may give rise to growing negative publicity surrounding mediation, as demonstrated by historical surveys. ${ }^{10}$ Hence, it seems, public policy administration engenders a shortto- medium-term perspective, emphasising government expenditure. By contrast, law engenders a long-term perspective, emphasising that the desire to embrace mediation too firmly (to generate savings) may withhold too many too long from court access; thus, too firm an embrace may 'kill the baby'.

10. A. de Roo and R. Jagtenberg, Settling Labour Disputes in Europe (1994), at 148ff., discussing some French longitudinal surveys in particular.

\subsection{Synergy between Disciplines: Common Contours Shining Through}

At first sight, the conclusion seems warranted that these projects, although involving various disciplines, do not evidence any particular inter-discipline at work. At closer inspection, that may be too rash a conclusion. Projects 2, 3, and 4 took place against a common background of diverse approaches towards settling conflicts and problems: approaches based on party autonomy and approaches based on the authoritative intervention of an outsider. Moreover, in projects 2 and 3, the autonomous approaches converged on mediation and the authoritative intervention on adjudication. In project 1 , the emphasis was on adjudication, but mediation (and other ADR mechanisms) necessarily came to the fore here too, in order to interpret figures accurately. Moreover, in projects 3 and 4, where the views of parties directly involved could be analysed, it appeared that conflicts were also ignored or avoided or one of the parties just gave in. Obviously, this whole range of options is always present in the background, whenever one tries to research the true role of judicial intervention in its proper context. In addition, one comes to realise that in order to explain the specific choice between mediation (or negotiation-based strategies generally) and adjudication, more needs to be known about the strengths and limitations of these approaches and about any (hidden) interdependencies between these. All these aspects shine through as contours of an inter-discipline in the making, wherever the true role of adjudication is the object of research. An inter-discipline in the making, not a vested inter-discipline as yet, because it is, I believe, not sufficiently clear yet which combination of methods emanating from which disciplines will appear as the most workable, consistent, and promising.

Any further discussion requires at least a brief introduction first to existing research into the range of conflict approaches, their characteristics, and their interdependence.

\section{Building Blocks of a Human Conflict Inter-Discipline}

So far some clashes and synergy between disciplines were encountered within the four projects.

The disciplines combined within these four projects do not represent all disciplines featured in research on the range of human conflict strategies, notably in publications on the distinction between strategies involving judicial intervention versus autonomous conflict resolution.

It makes sense to take a few steps back now, in order to gain a more comprehensive overview of the development of research generally, at the crossroads of judicial and autonomous conflict resolution.

A summary reconstruction of disciplines that have contributed to this field during the past 85 years suggests 
that early empirical insights generated by purely scientific motives have become increasingly 'hijacked' for practical application, especially since the rise of the modern mediation movement. This does not need to come as a surprise: research outcomes promoting autonomous resolution at the expense of judicial intervention were welcome in the light of austerity packages that have come to dominate the public sector (including the judicial system) across the Western world since the rise of Thatcherism and Reaganomics.

It is exactly this austerity bias in the amalgam of disciplines promoting autonomous over judicial conflict settlement that calls for a revaluation of the discipline of law. As pointed out in the second project I was involved in (Court-referred Mediation), the very concept of rule of law and equal protection under the law may thus come under pressure. This would be particularly detrimental to one-shotters and (other) disadvantaged addressees of the law.

A reorientation is necessary here, giving pride of place to insights that have become underexposed or which have newly emerged from critical countercurrents within some of the empirical disciplines discussed. Some of these useful insights are touched upon towards the end of part 3 .

A communis opinio on what constitutes the range of human conflict strategies has been generated from within ethology and conflict psychology. Walter Bradford Cannon first described the so-called fight-or-flight response to a perceived attack. ${ }^{11}$ His work was built upon and refined in regard to complex human conflict situations, inter alia by Blake and Mouton and notably Dean Pruitt, and eventually led to what has become known as the 'conflict management grid'. ${ }^{12}$ Within this grid, most authors today distinguish four main strategies that people facing a conflict will choose from, that is, a strategy of avoiding, yielding, solving, or confronting. 13 'Confronting' is about trying to get one's way onesidedly, overriding one's opponent. This strategy encompasses litigation in a court of law as a mild variety and the use of brute force as a remnant of fight. 'Solving' implies that parties discuss together the real causes of their problem and try to negotiate a mutually acceptable solution, often by each of them taking something and giving something else in return. ${ }^{14}$

\subsection{Practical Application: The Mediation Movement}

In relations between sovereign states, negotiation is traditionally the primary strategy resorted to, as the use of military force increasingly meets criticism in public

11. W. Cannon, Bodily Changes in Pain, Hunger, Fear and Rage (1929).

12. R. Blake and J. Mouton, The Managerial Grid: Key Orientations for Achieving Production through People (1964).

13. Dean Pruitt and his colleagues particularly. Inter alia: D. Pruitt, 'Strategic Choice in Negotiation', in W. Breslin and J.Z. Rubin (eds.), Negotiation Theory and Practice (1991), at 42-72. Pruitt uses 'inaction' instead of 'avoiding' and 'contending' instead of 'confronting'.

14. There is a linear relationship between negotiation, mediation, arbitration, and litigation in that these methods imply an ever-decreasing amount of control on the part of disputants. opinion, whereas law is, as yet, a rudimentary edifice in this area. In the 1950s, the US State Department commissioned Harvard researchers to find out whether its diplomats could be turned into more effective negotiators. The behavioural research that took place there combined cognitive and conflict psychology with (mathematical) game theory analysis. ${ }^{15}$ The insights that were gradually gained through experiments and analysis led to the recognition that negotiation was not merely an art to be practised by the talented but also has the potential to become a science. Roger Fisher and William Ury's work on effective negotiation in itself became the basis of the professional body of expert knowledge for modern mediators. ${ }^{16}$

Mediation represents one step up in the range of conflict management strategies from negotiation (solving) to litigation (confronting) and is usually understood as a process whereby a neutral assists disputants to find a way out of deadlocked negotiations. From that perspective, modern mediation is a derivative of effective or 'Harvard-style' negotiation. Such effective negotiation is based on a return to the underlying (possibly common) interests of the parties. Interests cannot be served well if the cognitive abilities of parties are derailed by strong emotions; 'negative misattribution' (attributing an evil motive to whatever conduct the other party engages in), 'reactive devaluation' (a party immediately distrusts an offer because their adversary made it), and 'judgmental overconfidence' (having too high expectations about one's prospects) are well-charted biases that will likely constitute impediments for constructive interest-based negotiations. Interests cannot be served either if parties adopt fixed positions in the usual course of conflict escalation. Such positions notably include legal positions, firmly taken to defend one's interests. But (legal) positions are likely to start a life of their own. The modern mediator has come to be regarded as being able to impart, in a well-structured process, more effective negotiation skills onto parties that found themselves mired in a dispute. This approach also carries the promise of empowerment of disputants; not only diplomats but - more importantly - also common people, individuals, entangled in any kind of dispute, ranging from a problematic divorce or a dismissal to a business partner defaulting on a contract, may be turned into competent and effective negotiators, through hands-on experience under the guidance of a qualified mediator.

In the aforesaid areas, a comprehensive legal framework tends to be present. This takes us to the domain of law, to sociolegal studies, and to public policy administration. In such areas as discussed, litigation in a state-funded court always constitutes an option. In the $1980 \mathrm{~s}$, in the USA initially (with the advent of Reaganomics), scholars appeared on stage, highlighting the need to curb public expenditure on the courts, by relieving the

15. Game theory plays a significant role in the work of $\mathrm{H}$. Raiffa, The Art and Science of Negotiation (1982).

16. R. Fisher and W. Ury, Getting to Yes. Negotiating Agreement without Giving in (1981), and later editions. 
courts from the burden of their allegedly excessive caseloads. Manning was one of those authors who pointed at society becoming ever more litigious in his provocative article 'Hyper lexis'. ${ }^{17}$ Such publications sparked off a debate with empirical sociologists like Marc Galanter and William Felstiner, who argued, inter alia, that too little was known as yet about the baseline of (legal) disputes, the causes of disputes, and the obstacles that addressees of the law had to overcome to have a case registered in a law court, to make any generalisations about litigiousness. ${ }^{18}$ Meanwhile, policymakers pursuing an agenda of budgetary restraint teamed up with the newly emerging profession of modern mediators, who had absorbed the Harvard insights and were looking for opportunities to put these into practice (and preferably make a living). Through the work of Frank Sander, who coined the notion of the 'multi-door courthouse', the phenomenon of court-annexed mediation began to develop, whereby judges would refer litigants to an external, qualified mediator to see whether their problem could not be solved that way, instead of having the case lingering through the court docket. ${ }^{19}$ Courtannexed or court-referred mediation also rapidly spread across Europe in the 1990 s and early 2000s. ${ }^{20}$ Critical sociologists have maintained that there is not a genuine demand for the services of mediators rather that this is a supplier-driven development.

At any rate, since policymakers were won to the idea that judges, as public authorities, were to refer litigants to the private sector (mediators are essentially selfemployed), surveys mapping customer satisfaction were commissioned, and the need for professional-ethical requirements for mediators was put on policy agenda's across Europe. Gradually more studies appeared, mostly commissioned by government authorities, calculating the costs involved in state-funded litigation, whereby mediation became increasingly seen as a smart economising tool. In official documents, mediation was presented primarily as an additional option to achieve 'justice' for many. It is noteworthy that in many documents, the concept of 'access to court' became replaced by 'access to justice'.

\subsection{The Austerity Bias}

Overlooking this field, what seems to emerge is a patchwork of connections between disciplines, referred to here as conflict management studies. Thereby, only the range of conflict options originally identified by ethology and refined by conflict psychologists appear as having been inspired by purely scientific motives, that is, curiosity, without a desire to put the accumulated

17. B. Manning, 'Hyperlexis: Our National Disease', Northwestern University Law Review, at 767ff. (1977)

18. W.L. Felstiner, R.L. Abel \& A. Sarat, 'The Emergence and Transformation of Disputes. Naming, Blaming, Claiming', in K. Schuyt, K. Groenendijk \& B. Sloot (eds.), (15) Law \& Society Review (1980); K. Schuyt, K. Groenendijk \& B. Sloot, De weg naar het recht (1976).

19. F.E.A. Sander, 'Varieties of Dispute Processing', in A.L. Levin and R.R. Wheeler (eds.), The Pound Conference: Perspectives on Justice in the Future (1979).

20. De Roo and Jagtenberg, above n. 6. knowledge to immediate practical use. Harvard negotiation research (based on conflict psychology and game theory) was carried out for practical application (initially in diplomacy) although it certainly has been conducive to scientific knowledge accumulation that is empirical findings that can be tested (also experimentally) by others in the scientific community. The same applies to most of the sociolegal studies into court-referred mediation. This particular amalgam of disciplines appears to be sustained in a kind of symbiosis, incentivised by governments and - where the courts are concerned - by (disguised) austerity motives in particular.

Were the critical sociologists right then with their conclusion that mediation is simply supply driven? I believe that goes too far. Although one may be distrustful of the motives that have come to underlie the campaigns for mediation, there is considerable evidence that disputants who have tried mediation are quite satisfied and prepared to resort to mediation again in future disputes. Also, mediations that are in no way connected to the courts are growing in number. In that sense, mediation and notably the underlying psychological insights and empirical underpinnings definitely have something to add to the whole spectrum of conflict resolution strategies. In my view as a legal scholar, however, the current symbiosis of disciplines is tilted too heavily towards the austerity motive. To grow out into a genuine interdiscipline, it will be necessary that aspects of conflict strategies that have remained underexposed so far (exactly due to the austerity focus) are taken on board yet. Thereby, strategies such as 'avoidance' and 'yielding' will pose a real challenge to legal researchers. The same applies to the whole issue of costs. Are there costs involved in avoidance or yielding? And costs for whom? This aspect may be adequately tackled within economics - thanks to new schools of thought that are developing exactly to address these underexposed, if not hidden, aspects of reality. ${ }^{21}$ In the wake of the financial crisis, a reorientation can also be observed within the domain of policy administration and political science, where the need for proper checks and balances is reasserted again. ${ }^{22}$ I believe that by integrating these new orientations in research, the current bias in the amalgam of disciplines may be redressed, and research will become what it should be, i.e. aimed at observing, understanding, and possibly explaining the whole of reality. Such a quarter-turn rotation away from the austerity agenda will make conflict management studies a coherent and sustainable inter-discipline that will prove extremely valuable to legal research. Before going into that, I will first indicate my personal assessment of the usefulness of insights currently generated by mediation-focussed research (as this is as yet the conflict strategy most closely connected to the domain of law); this assessment will be followed by an analysis of how the current

21. An important role is played here by the London-based New Economics Foundation, confessing to 'economics as if people and the planet mattered'.

22. In the Netherlands, e.g. the 2011 RMO report Tegenkracht organiseren, downloadable from the RMO website. 
insights have been incorporated (or not) in academic legal research - the core theme of the symposium.

\subsection{Useful Insights: A Personal Assessment}

\section{The Perspective of the Disputant}

Pruitt's conflict management grid and Felstiner's conflict transformation pyramid help us in understanding the disputant's perspective. It is important to realise that for disputants, litigation is often only an option of last resort. Which preliminary choices does a disputant make when facing a (legal) problem? Which quality does a disputant regard essential in a 'neutral', and how will this co-determine his or her strategy? How does a disputant react to early professional interventions? How do conflicts (de-)escalate? When are they really solved, and at what cost to the disputant? Here, legal practice and legal academia can catch sight of the hinterland of the legal services 'market', on which they both thrive. The discussion on court-referred mediation particularly has been conducive to various fundamental studies being undertaken in the Netherlands, such as the Dispute Resolution Delta (Geschilbeslechtingsdelta). ${ }^{23}$ In this project, which is still continuing and expanding, stock has been taken of what makes disputants decide for one or the other strategy. In doing this, the 'Delta' constitutes a more sophisticated and elaborated version of the dispute resolution pyramid model developed by Felstiner and his colleagues (which distinguishes between just three filters from the baseline upwards, i.e. disputants' ability of naming, blaming, and claiming).

\section{The Notion of Interests}

The 'interests' notion is not wholly absent in the law in substantive law, for example, in the relativity requirement for tort liability or the abuse of right doctrine, in procedural law in the requirement of standing. But the ambit of the 'interests' notion as used in Harvard negotiation theory is much wider. Disputants who have walled themselves into a legal position may lose sight of their underlying interests. This becomes even more likely once a lawyer takes over, because the lawyer will urge the disputant to reduce his reality, that is, to discard feelings (that the disputant would love to vent) and to discard all those facts that do not support a legal position to be taken in court. ${ }^{24}$ Keeping the parties focused on their interests as in mediation may indeed deliver solutions that serve both parties' interests in an optimal fashion, though not necessarily in all cases.

\section{The Role of Professional Neutrals, How These Are} Financed and What Their Interests Are

The debate on pros and cons of mediation in comparison with in-court adjudication has led researchers to touch upon the sensitive - but important - topic of professional self-interest. The critics of mediation have

23. B.C.J. van Velthoven and M. ter Voert, Geschilbeslechtingsdelta 2003 (2004). Also: Hazel Genn, Paths to Justice (1999).

24. A. de Roo and R. Jagtenberg, 'The Relevance of Truth, the Case of Mediation vs. Litigation', in R. van Rhee \& A. Uzelac (eds.), Truth and Efficiency in Civil Litigation (2012), at 1-20. never ceased to point at the mediator's need to make a living and to do about everything to secure a steady influx of cases. ${ }^{25}$ The continuous surveys on mediator performance, customer satisfaction, and ethical requirements as monitored by supervisory bodies have eventually reverberated; it seems, into the domain of the judiciary as well. Although mediators as an emerging profession are still under more scrutiny than judges as an established profession, judicial strategic behaviour does no longer escape the attention of researchers. ${ }^{26}$ As one British scholar summarised: 'The problem is that judges have too many cases, and mediators have too few. ${ }^{27}$ Not only considerations of caseload and (fixed) income play a role: the personal feelings of judges about mediation and about their own professional role likewise appear to play a role in their willingness to refer litigants to mediation or to do the opposite. This has been an interesting insight in project 2 particularly, where we were confronted with erratically jumping patterns of court referrals, notably in France; investigating these more in depth, evidence was retrieved about the decisive role of the personal enthusiasm (or otherwise) of individual judges - despite a uniform regulatory regime. ${ }^{28}$ And then there are the financial incentives and constraints for publicly funded judges and for self-employed mediators. Put briefly: judges will be tempted to attune their output to fit their fixed salary or budget, by minimising labourintensive work on cases; mediators will try to secure output any way they can so as to maximise their income. So both professions may be prone to strategic behaviour. $^{29}$

\section{$4 \quad$ Costs and Returns for Various Groups of} Stakeholders

Disputants inter se, disputants and a mediator, or disputants and a judge may be regarded as the actors who are directly involved in the activity of dispute resolution. In an economic sense, the activity could be regarded as a 'transaction' that may give rise to positive or negative 'externalities': other people further afield may benefit from or may be harmed by the approach taken by those directly involved. This may be society as a whole, and it may also be a corporate entity, an organisation as a whole, such as (returning to project 3 for a moment) the Netherlands police force. Daniel Dana has been among the pioneers to design tools for calculating

25. N.J. Huls, 'De aanbodeconomie van ADR; mediation kritisch beschouwd', (9) Justitiële Verkenningen, at 99-107 (2000).

26. R. Jagtenberg and A. de Roo, 'Mediation and the Concepts of Accountability, Accessibility and Efficiency', in R. van Rhee and A. Uzelac (eds.), Access to Justice and the Judiciary (2009), at 149-71.

27. R. Ingleby, 'Court-Sponsored Mediation; the Case against Mandatory Participation', Modern Law Review, at 441-51 (1993).

28. H. Touzard, M. Bastounis \& I. Benharda-Piget, Les représentations socials du règlement des litiges. Le cas des modes alternatifs (avril 2001).

29. On the judiciary, see A. Kronman, The Lost Lawyer. Failing Ideals of the Legal Profession (1995); on mediators: B. Baarsma, Blifft mediation de eeuwige belofte of wordt het een volwassen markt? (2011). 
the costs of escalating organisational conflict. ${ }^{30}$ In project 3, we have built upon Dana's findings, developing his model into different directions, inter alia, so as to include the costs for individual employees. In regard to projects 1,2 , and 4 , it would be extremely relevant to chart where costs and returns would arise elsewhere in society. In project 4 , for example, enhancing the problem-solving power of family networks could be conducive to a growth in 'social capital'. ${ }^{31}$ Newly engineered research methods such as social return on investment (SROI) analysis make it possible to monetise 'value' effects of actions for stakeholders elsewhere in society, in a fairly reliable manner, thus enabling to deal with the 'whose costs?' question less one-sidedly and more comprehensively. ${ }^{32}$ In regard to projects 1 and 2, where the choice is between adjudication in the public domain and negotiation in a private conference room, many more aspects could thus be brought to bear, such as the social returns generated by a well-functioning judiciary. ${ }^{33}$ The words of warning that Yale law school president Anthony Kronman already expressed in the 1990s against the one-sidedness of 'managerial judging' may then finally receive a satisfactory answer. Kronman observed that managerial judging is essentially a program of economic reform, premised on the belief that a reallocation of judicial effort from the courtroom to the conference table can mitigate the inefficiencies of the queue-based system of adjudication and thereby increase the amount of justice that the courts are able to produce with the resources committed to them. But, Kronman wonders, is it really clear what exactly a judge seeks to maximise (in comparison to - for example - a manufacturer of pencils)? The 'commensurating drive' of (orthodox) economics, i.e. to translate all inputs with different qualities into the single property of costing money, may seriously distort this strive for increased efficiency. In conflicts over fundamental values, it may be better exactly not to wrench these out of the perspective in which they are viewed by the parties. ${ }^{34}$

30. Annie de Roo, 'Interview with Dr. Daniel Dana; The Inventor of Financial Cost of Organizational Conflict and the Advocate of Self-Mediation', 3 Nederlands-Vlaams tijdschrift voor mediation en conflictmanagement, at 6-16 (2008).

31. R. Putnam, Bowling Alone: The Collapse and Revival of American Community (2000)

32. J. Nicholls et al., A Guide to Social Return on Investment (2012).

33. A.H. van Delden, Wat is de rechter waard? Rechtspraaklezing (2006).

34. Kronman, above n. 29, at pp. 338-40. Reference is also made to R. Dworkin, 'Is Wealth a Value?', 9 Journal of Legal Studies, at $191 \mathrm{ff}$. (1980); D. Scheele, Doelmatigheid in de rechtshuishouding; een rechtseconomische anlyse (2006).

\section{The Incorporation of Findings in Legal Scholarship, Legal Practice, and Legislation}

From here, it is a small step into legal practice and legal academic scholarship to take stock of how the insights and findings of the current amalgam of research into alternative modes of dispute resolution (tilted as it is towards austerity agenda's) have been incorporated or not.

\subsection{The Incorporation in Legal Practice}

Since legal practice largely constitutes the object as well as the audience for doctrinal academic legal research, it makes sense to start this investigation into the incorporation issue here. In so doing, I will have to confine myself to the Netherlands, since the research projects had been commissioned by the Netherlands' government for valorisation in this country. ${ }^{35}$ The nationwide experiments that took place during the first decade of this century have resulted in the incorporation of mediation facilities in all courts, except the Supreme Court. This reflects recognition of at least the next adjacent mode of dispute resolution, i.e. negotiation-based mediation, as a valid alternative for a number of disputants. This 'institutional' incorporation, in turn, has led to some further incorporation of findings and ideas in the daily practice of judges and of lawyers in private practice (advocatuur). This is important, because one can have a facility, but a facility will be used only if it is alive in the minds of its potential users. Apart from the disputants themselves, one could say that the key actors in referrals are judges and, at an earlier stage, the lawyers engaged by disputants. Among the judiciary, some selective incorporation can be observed. The insight that (sometimes) qualitatively better solutions can be achieved through mediation has been instrumental for some Dutch courts to embark on multi-annual experiments with a so-called conflict diagnosis model, developed largely by psychologist Martin Euwema. ${ }^{36}$ The experiment fits in with a newly developed concept, conflictbeslechting op maat, that is, tailor-made dispute resolution. The underlying idea is, obviously, that it is possible to diagnose which dispute strategy is best in which case: mediation or adjudication. This experiment takes place at the moment parties have submitted their case to court. Cooperation in this experiment is voluntary for judges and in that sense self-selective: judges who are indifferent or even opposed to mediation will not take part anyway. At any rate, one could argue, with refer-

35. For an international overview, reference is made to $A$. de Roo and R. Jagtenberg, 'Professional(s as) Mediators: Emerging Markets and the Quality of Legal Protection', in A. Uzelac and C.H. van Rhee (eds.), The Landscape of the Legal Professions in Europe and the USA: Continuity and Change (2011), at 235-54.

36. M. Pel and S. Verberk (eds.), De pilots 'Conflictoplossing op maat'. Reflectie op resultaten en ideeën voor de toekomst (2009). 
ence to the dispute resolution pyramid concept, that the courtroom is already many steps away from the very baseline where the conflict arose for the first time.

In the lower regions of the dispute resolution pyramid, however, incorporation can be observed too, notably among lawyers. Lawyers must be aware that, if they pursue their client's case in court, judges may raise mediation as an option that might be considered. As an enterprising professional, lawyers have to anticipate that question, and so, they will have to discuss mediation as an option long before with their client, so as not to be taken by surprise in court. It is less relevant, I think, to dwell on the possible motives for lawyers to raise the mediation option directly with their clients; whether they genuinely believe this may be a better avenue, whether they feel it can be used as defensive marketing, or whether mediation could fit in a 'appearing reasonable' strategy: in all instances, mediation and the underlying insights from conflict psychology are finding their way down the lower regions of the dispute resolution pyramid. ${ }^{37}$ My colleagues and I have coined this phenomenon as 'the shadow of the referral', a designation that builds on Robert Mnookin's famous concept of 'the shadow of the law'. ${ }^{38}$

One may wonder whether still lower down in the dispute resolution pyramid, also in-house counsels, that is, corporate lawyers and government lawyers, have incorporated the findings generated by the amalgam of disciplines described above. From the agendas of relevant professional associations, various reports, and experiments, it appears that there is at least a growing awareness of the need to consider more alternative methods, which each may have their rationale. Interestingly, however, the larger the corporation or government body, the less such an entity appears to be inclined to acknowledge the potential benefits of independent mediators. There is a clear tendency for such 'big players' to either deploy their own in-house mediators or merely to incorporate the insights and negotiation skills into their own HRM training programs, thus turning these into the functional capabilities required from their staff. ${ }^{39}$

\subsection{The Incorporation in Academic Legal Scholarship}

Again, I will confine myself to the Netherlands here. Moreover, even within this single jurisdiction, it will be obvious that a thorough analysis of all academic legal

37. A further consideration pro mediation might be its finality: various surveys that found a much better compliance record for mediated settlements once achieved than for court verdicts. See L. Combrink-Kuiters et al., Ruimte voor mediation, WODC Onderzoek en Beleid, nr. 210, (2003)

38. R. Mnookin and L. Kornhauser, 'Bargaining in the Shadow of the Law', Yale Law Journal, at $88 \mathrm{ff}$. (1979); Courts may render judgments in only a fraction of all meritorious cases that emerge at the baseline of society. But the effect of those judgments will be much wider and also set the parameters for those disputants who follow the strategy of negotiation or mediation.

39. De Roo and Jagtenberg, above n. 35. Also D.B. Lipsky and R.L. Seeber, 'In Search of Control: the Corporate Embrace of ADR', University of Pennsylvania Journal of Labour and Employment Law, at 133-57 (1998). research is physically impossible. A simple illustration: compiling the 2009 evaluation report on legal research in the Netherlands (the Koers Committee report Kmaliteit ES Diversiteit) took a whole year. ${ }^{40}$ I will instead concentrate on the Grosskommentar par excellence for Dutch private law, the Asser series, and on the best known handbooks on the law of civil procedure. At this point, the international ELR readership may be tempted to scrutinise their domestic doctrinal works in a similar vein.

With regard to the Netherlands, it is interesting to read in the Koers Committee report that a clear shift can be observed from mono-disciplinary to multidisciplinary research, that there is more attention for methodological issues than a decade before, and that legal research is increasingly financed through external research funds for which researchers have to compete with each other.

Turning to the Asser series first: in this voluminous series, only one volume addresses the plurality of dispute resolution methods in some detail, that is, the 2005 Algemeen Deel, the 'General part' of the series, edited by Jan Vranken, Professor of Law at Tilburg University and Advocate-General with the Netherlands Supreme Court. ${ }^{41}$ The issue of comparing modes of dispute resolution features in a chapter entitled 'the move away from the state-funded judge' (Weg van de overheidsrechter). It is noteworthy that Vranken had already been involved as one of three leading legal scholars in a project on fundamental reassessment of civil procedure (de Fundamentele Herbezinning), a project that also aimed to integrate relevant sociolegal findings and insights from psychology. ${ }^{42}$ In the Asser series volume, Vranken characterises mediation as 'the most radical' of all other alternatives to adjudication, in 'its exclusive focus on the individual', and solving the individual's conflict by addressing underlying personal interests, including human emotion. However, Vranken continues, this also seems a weakness of mediation; it is too much inward looking and lacking in transparency. This is worrying because at the same time there may be a connection with law, notably where legal rules constitute a standard for objectivity that a mediator may bring in to circumvent negative misattribution. Where the law comes in, mediation should be much better regulated, according to Vranken, if only to guarantee that each disputant is granted equal opportunities. The bottom line is, according to Vranken, that it is questionable whether one can safely assume, as mediation does, that average human beings are able to oversee their own problems and to take rational steps.

40. A.W. Koers et al., Kwaliteit en Diversiteit: Rechtswetenschappelijk Onderzoek in Nederland - Rapport van de Evaluatiecommissie Rechtswetenschappelijk Onderzoek, Amsterdam: VU, 2009 (432 pages).

41. J.B.M. Vranken, Mr. C. Asser's Handleiding tot de Beoefening van het Nederlands Burgerlijk Recht. Algemeen Deel - Een Vervolg (2005).

42. M. Barendrecht and A. Klijn, Balanceren en Vernieuwen, Een Kaart voor Sociaal-Wetenschappelijke Kennis voor de Fundamentele Herbezinning Procesrecht (2004). 
In view of legal standards possibly playing a role when it comes to infusing objectivity in the mediation process, Vranken thus concludes that mediation should become the object of more (legal) regulation. To some extent, as I will come to illustrate below, this desideratum has been taken on board in the draft bill on mediation that has been introduced by former MP Van der Steur, presently the Minister of Security and Justice.

First, however, two authoritative handbooks on civil procedural law are to be reviewed on the incorporation issue. Hugenholtz-Heemskerk (2012 edition, 350 pages) devote half a page to mediation in a chapter entitled: 'arbitration and expert determination' (arbitrage en bindend advies). ${ }^{43}$ This is curious, as arbitration and determination constitute methods whereby a decision is being imposed to end the conflict. Viewed against the basic range of dispute resolution methods, these are rather shades of grey within the confrontational strategy, casu quo litigation. The chapter on mediation has a very introductory character and focuses on the courts as agents of referral of intending litigants. The source material in the footnotes consists almost exclusively of commentaries written by authors with a background in law. Likewise the well-known handbook by Snijders and his colleagues (2011 edition, over 600 pages). ${ }^{44}$ Here about three pages are devoted to mediation in a chapter entitled 'private means of recourse to law' (private rechtsgangen). Again, this is curious as mediation, and negotiation-based strategies generally are not modes of recourse to the law. Again, the source material incorporated in the footnotes consists almost exclusively of commentaries written by lawyers. In addition, Snijders et al. have included some Supreme Court judgments on mediation, in relation to court procedure. For completeness sake: neither Snijders and his colleagues nor Hugenholtz-Heemskerk have separate entries on (direct) negotiation, as the most pure variety of a 'problem solving' strategy.

The conclusion seems justified that other modes of dispute resolution as exposed in conflict management studies are essentially 'cannibalised' in publications that adopt an internal perspective on the law, i.e. doctrinal legal academic writing. The available information is fundamentally reduced and translated into the perspective and language of the law, so as to make it fit the law's disciplinary straightjacket.

Authors who attempt to adopt an external perspective albeit for just a moment (like Vranken) appear to be inclined to resort to regulation, in order to make mediation concordant with the law. It is interesting to note that Vranken did not mention any need for direct negotiation to be regulated.

Finally, it is noticeable that hitherto, only one professorial chair on dispute resolution methods has been established within a law faculty thus far (i.e. the Free University of Amsterdam); at closer inspection, however, it

43. W.H. Heemskerk, Hoofdlijnen van het Nederlands Burgerlijk Procesrecht (23rd edn) (2012), at $223 \mathrm{ff}$.

44. H.J. Snijders et al., Nederlands Burgerlijk Procesrecht (5th edn) (2011). appears that the focus of that chair is on intervention by expert witnesses in court procedures. A more comprehensive program that was established some years ago at another university (Utrecht) has been largely dismantled already, due to major budgetary cutbacks.

\subsection{The Legislator Role and the Role of the Legislator}

Understood in its broad meaning, doctrinal academic legal research includes the formulation of recommendations for legislation, i.e. the researcher assuming a 'legislator role'. In regard to project 2, discussions took place in the years following the nationwide experiments mentioned above as to how to structure court-referred mediation in the Netherlands.

It soon became clear that certain quarters were pushing for a more mandatory referral scheme, to be introduced in Dutch law. Elsewhere in Europe, mandatory referral had already been introduced, notably in Italy. In the Netherlands, the former MP Van der Steur initially sought inspiration in Italy for his proposals on mediation legislation. Actually, Mr. Van der Steur's proposals concern three different subjects (contained in three different bills): one bill seeks to regulate the profession of mediator. ${ }^{45}$ In the wake of a 2008 European Directive seeking to establish a professional privilege for mediators, without however regulating the professional requirements for mediators, the first bill aims to create a legally protected professional title: registermediator or $\operatorname{Reg} M$ (registered mediator). A $\operatorname{Reg} M$ will have to comply with strict professional requirements, inter alia a minimum of legal knowledge and a minimum of practical experience, in order to be registered in a new system under the aegis of the Minister of Justice. Professional privilege will only accrue to $\operatorname{Reg} M \mathrm{~s}$; courts may only refer litigants to $\operatorname{Reg} M \mathrm{~s}$; and $\operatorname{Reg} M \mathrm{~s}$ will be given the power to liaise directly with the courts when a legal issue arises during mediation or whenever parties seek to have their settlement being made enforceable. So far, the desideratum expressed by Vranken has received a follow-up, it seems. The second Van der Steur bill aims to 'anchor' mediation firmly in civil procedure. ${ }^{46}$ To this end, the bill ties mediation in with the legal process in various ways. It provides that in the writ of summons, the claimant will have to explain why mediation has not been attempted. The judge may then decide to refer the case to mediation yet, if in his opinion the case would lend itself to mediation. Moreover, disputes will be presumed to be suitable for mediation whenever they involve a 'relational' aspect; this includes at any rate all contractual disputes. The third Van der Steur bill contains comparable provisions for administrative law procedure, albeit that there the government party will have to clarify whether it sees mediation as an option. ${ }^{47}$

It is interesting to see that the second bill attempts to make mediation less voluntary, in the context of court procedure. In so doing, my impression is that the really

45. Wetsvoorstel (Bill) nr. 33722

46. Wetsvoorstel (Bill) nr. 33723

47. Wetsvoorstel (Bill) nr. 33727 
important findings and insights from conflict management studies have not been incorporated or have been incorporated only selectively.

The primary criticism that my colleagues and I have expressed in various publications is that the dispute resolution pyramid model illustrates a bias among policymakers in Ministries of Justice and now even in Parliament. ${ }^{48}$ They are entirely focused on the issue of how to signpost a very small group away from the courtroom to a mediation conference room. This is the small group of intending litigants who have made a number of choices already underway, from the pyramid baseline all the way up, and who have now finally reached the courts. The Dutch Dispute Resolution Delta survey estimates that this group constitutes less than $4 \%$ of all disputants who have become involved in a legal dispute. But then, governmental policymakers will argue that they simply do not have a mandate for addressing the lower regions of the dispute pyramid. That point has been made at several occasions. In regard to the Van der Steur legislative proposals particularly, my colleagues and I also found, drawing upon the disputant perspective again, that policymakers arguing in favour of mandatory referral love to highlight frivolous cases that obviously do not 'belong' in a court. But how about the cases that do 'belong' in court but never got there and perhaps never got there because the litigants were persuaded to drop a potentially interesting legal argument for a private settlement negotiated somewhere in a conference room, thus for perverse reasons (intimidation, lack of resources)? This aspect should also be borne in mind by the legislator: Are we sufficiently aware of the danger of compulsion, which may prevent issues to come out into the open that should indeed have been made public?

The crucial question then becomes: who decides on what basis which issues in which disputes exactly lend themselves for adjudication and which for private negotiation (whether or not with the assistance of a mediator)? It is important to underline that an evidence-based framework for assessing the appropriateness of different conflict strategies accurately is simply still lacking.

These observations by my colleagues and myself have been taken on board by the Netherlands Council of State (Raad van State). ${ }^{49}$ Yet it remains to be seen whether the proposals will be amended, in view of such mere scientific considerations. There is still the tilting towards the austerity agenda that can be uncovered behind the proposals, possibly enhanced by some lobbyism from certain segments within the mediator community.

48. A. de Roo and R. Jagtenberg, 'Quasi-vrijwillige Mediation; Enkele Kanttekeningen bij de Initiatiefwetsvoorstellen Mediation', 17(2) Nederlands-Vlaams Tijdschrift voor Mediation en Conflictmanagement, at 35ff. (2013).

49. Raad van State, Advies W03.13.0323, 0324 en 0325/II, d.d. 22 November 2013.

\section{The Case for 'Reverse Incorporation'}

The conclusion so far must be that doctrinal academic legal research has hardly incorporated the empirical foundation of conflict management studies full scale. Only some findings pertaining to mediation, as the alternative directly adjacent to adjudication, have found their way into legal literature but only to the extent that courts may refer litigants to mediation, and then still, only the legal intricacies were on the minds of legal doctrinal authors. Vranken expressed a need for regulation as he held mediation to be too narrow in outlook; that is to say too much focussed on the feelings and perceptions of the individual and caring too little about inequality compensation. This is intriguing as the advocates of mediation would exactly find the legal approach to be too narrow, reducing the complexity of human conflict to make it fit within a legal straightjacket while hardly caring at all about the individual disputant. In my view, this quandary cannot be solved unless and until the disciplines relevant to conflict resolution have developed a better understanding for each other and some of the selective orientations within each of these disciplines will have been addressed. Most of all, the disguised tilt towards the austerity agenda must be eliminated from the current amalgam of disciplines, in order to give it a purely scientific, consistent, and sustainable basis that will allow it to develop into a genuine interdiscipline ('conflict management studies'). I will hint at some of these selective orientations and misunderstandings first and sketch what sort of questions I think should be on the research agenda of a genuine inter-discipline for the next ten years. I will then conclude this article with some reflections as to how doctrinal legal research could find a proper place within this new interdiscipline.

\subsection{Getting Things Straight and Restoring the Vista}

Let us start this short impression within the discipline of law, quoting Owen Fiss, from his 1981 landmark contribution to the ADR debate, 'Against Settlement':50 'The social function of the lawsuit is to explicate and give force to the values embodied in authoritative legal texts; in case of settlements, society gets less than what appears, and for a price it does not know it is paying.' There are at least two points to be made here. First, in much litigation, neither the facts are self-evident nor is the law unequivocally clear; think, for example, of those frequent cases where both parties have acted negligently. This aspect is also missed in the economic analysis of law. Viewing legal rules as an institutional framework for the market, economists seem to presuppose that cases and rules are always crystal clear. Negotiations in the shadow of the law are therefore disqualified as a 'you

O. Fiss, 'Against Settlement', 93 The Yale Law Journal (1984). 
quit first game', that may disincentivise efficiency. ${ }^{51}$ It is often a fact of life, however, that disputants are justifiably struggling how to offset the uncertain outcome of litigation against the certainty of a settlement. Are the psychologists, who have played such a dominant role in furthering modern mediation, right then? The insight that mechanisms in our brain may prevent us from a constructive approach in conflict situations is highly valuable, but conflicts are not only about cognitive deficiencies. Many (and probably most) conflicts are also about conflicting tangible interests that may be so important that laws have been made to protect these. Hence, sometimes the psychologists' perspective may be too 'micro' indeed. Harm may be caused not only to an easily impressed disputant but also to an organisation or society at large if cognition is overemphasised. Back to Owen Fiss then and the concept of externalities? But how does law and economics deal with vertical relationships, that is, where the law bestows power to particular functionaries and makes such functionaries practically invulnerable? In the present era of financial crisis, cases come to the fore almost on a daily basis where political or business leaders found the law on their side when their subordinated opponents sought to blow the whistle about negative externalities arising elsewhere in society. Is this the law that Owen Fiss seeks to uphold? There is some psychology involved in here too. ${ }^{52}$ Quoting from an interview I had with Daniel Dana in 2008, on the absence of rational systemic approaches to deal with organisational conflict: 'Who really cares about costs? It is discouraging that seemingly no one cares. You would expect shareholders to care. But I don't think they will, because the personal embarrassment when attention is drawn to a conflict is a higher personal priority in the moment than the longer term financial consequences of the conflict experienced.'

Open conflict, in other words, is taboo. This takes us to the full-scale range of conflict management approaches, notably the options of avoiding and yielding, and the costs these may entail; these are all notorious blind spots in legal research. I would say that multidisciplinary research on conflicts should be redirected to these aspects; such research would materialise the breakaway from the austerity agenda, which is set by those in power defining which costs are to be regarded as costs; at the same time, such reorientation may yield significant social returns. In the slightly longer run, it may be instrumental in setting the amalgam of disciplines 'upright' again, allowing it to develop critical thrust for the way forward in conflict knowledge.

\subsection{In Conclusion: How Would Legal Research} Fit into This New Inter-Discipline?

A key feature of the new inter-discipline in the making is the disputant perspective. This perspective does not

51. For example, the economic analysis of the provisions on 'hardship' in the Principles of European Contract Law and the Draft Common Frame of Reference; F. Chirico and P. Larouche, Economic Analysis of the DCFR (2010)

52. And psychiatry as well: R. Babiak and R. Hare, Snakes in Suits (2008). rule out that, in addition, the judicial or legislator perspective can be adopted, but the disputant perspective is crucial if one is to get the complete picture of conflict strategies available.

Interestingly, lawyers in private practice are more accustomed to connect the disputant perspective to the judicial perspective. As Susskind has argued in his provocative essay 'The End of Lawyers?', in order to survive, it is only becoming more and more important for lawyers to take cognisance of the disputant, that is, their client's perspective. ${ }^{53}$ The legal services market is becoming extremely competitive, and information technology and ADR are increasingly making inroads on traditional legal work.

Since legal practice is the object and also the target audience of doctrinal legal research, this cannot remain without consequences. It may force academic doctrinal researchers not only to think more outside the legal box but also, and paradoxically perhaps, to think even more from a lawyer's client perspective. After all, published court reports hardly ever tell us what the dispute was really about; in continental European countries, the succinctness of those reports may even have cut out a wealth of legal arguments that were actually used inside the court room, under the pressure of judicial performance indicators (the tilt towards austerity) that require a swift result that lend itself for accounting purposes. To be sure, the need to sit next to the client/disputant, as it were, will likely impose some methodological challenges. Ideally, also this kind of research should extend over different jurisdictions, selected not only on the basis of traditional cultures but also of expected differences in economic pressure on the judiciary. ${ }^{54}$

Doctrinal legal research will also be incentivised to move up this way, that is, adopting the disputant's perspective, by the changing structure of academic research itself. It may be sobering to learn that Europe's primary financier of academic research today, the European Research Council (ERC), distinguishes between only three main branches of research: (1) physical sciences and engineering (44\% budget share), life sciences (medicine, biology) (39\% budget share), and social sciences and humanities (17\% budget share). Law is not even recognised as a subdomain of research in its own right, but always linked to one or more specific sub-branches of the social sciences. The upshot is that legal researchers will have to demonstrate what exactly they are adding to solve the problems of the real world, and this requires the cooperation with empirical disciplines, tout court. To conclude on a recurring theme in this article: not only is the behaviour of lawyers, judges, and mediators influenced by the financial structure in which they work, the same applies to legal academics!

53. R. Susskind, The End of Lawyers? (2008)

54. There are strong indications that the legal parameters for the profession of lawyers has changed in correlation to a more liberal or more protectionist outlook of the economy, in the past. For a comparative insight, see R. Jagtenberg and A. de Roo, 'Internationalisation of Legal Services and Markets in Europe and Asia', Japon in Extenso, Poitiers, no. 47-48, at $36 \mathrm{ff}$. (mars-juin 1998). 
The point I want to make however goes beyond the mere necessity for doctrinal legal researchers to subsume their research under a broader interdisciplinary heading; I find it also desirable for both legal and for empirical researchers that such a reverse incorporation materialises, ironically perhaps to countervail some tendencies towards one-sidedness that can be observed within empirical research focussed on human conflict. As discussed above in paragraph 2.3 (clashes between disciplines), my own experience is that legal doctrinal research, exactly because of its normative stance, has something crucial to add to the 'naked data' that are collected through the restrained prisms of distinct empirical subdisciplines, particularly where empirical studies are tilted by the austerity motive - think of the misguided conclusions based on mere productivity data of courts or the absolute quantity of compulsory settlements. After all: the 'ought' of the law is in itself a part of the real world too. 